\title{
THE STRANGE BIOGRAPHY OF SAMSON
}

\author{
Yair Zakovitch
}

\begin{abstract}
A в s t R A с т The biblical story of the life of Samson hides much from the reader; the Book of Judges has deleted from the story elements that were deemed improper for the book's placement among the Holy Scriptures. In this article, the author shows how the Bible transforms Samson from a mythological hero, the son of a god, to a mere mortal whose extraordinary strength came through the spirit of God that rested with him so long as he kept his Nazirite vows. The biblical storyteller could not prevent the story of Samson from entering into the biblical corpus since it was a tale of tremendous popularity. He thus told it in such a way as to bring it closer to his monotheistic beliefs and world-view. In its 'biblical' form the story does not bring honor to the figure of Samson, and so his placement as the last of the judges in the Book of Judges prepares the reader for the establishment of the institution of kingship, in the Book of Samuel.
\end{abstract}

$\mathcal{B}$ efore turning to the life story of Samson, the subject of this article and the last of the judges in the Book of Judges (chapters 13-16), it is worthwhile first to lift our sights and peer out at biblical historiography, looking particularly at the correlation between the history of Israel and its sins against God, on the one hand, and the portrayal of the leaders that God appointed for His people, on the other. This is legitimate pursuit since we commonly trace Israel's history by way of its leaders: Moses, Joshua, Israel's judges and kings. ${ }^{1}$ Monarchies existed before Israel became a people. The book of 
Genesis knows of Nimrod King of Babylon (Genesis 10:3-10), Pharaoh King of Egypt (12:15ff.), Abimelech King of Gerar (20:2ff), as well as 'kings who reigned in the land of Edom before any king reigned over the Israelites' (36:31). In Israel, on the other hand, where God was king, no king rose until the people requested it, petitioning in their law code to be like other nations. The Law of the King-the only law in the Torah that mentions the institution of the monarchy-states: 'If, after you have entered the land that the Lord your God has assigned to you, and taken possession of it and settled in it, you decide, »I will set a king over me, as do all the nations about me...»' (Deuteronomy 17:14; cf. 1 Samuel 8:8). Kingship represents a rejection of God's rule and is not looked on favorably in the Bible, as we hear when God directs Samuel to yield to the people's desire for a human king, 'and the Lord replied to Samuel, »Heed the demand of the people in everything they say to you. For it is not you that they have rejected; it is Me they have rejected as their king' (2 Sam 8:7).

Israel was initially led by the prophets Moses and Joshua, but following Joshua's death came a crisis of faith: 'Joshua son of Nun ... died ... And all that generation were likewise gathered to their fathers. Another generation arose after them, which had not experienced [the deliverance of] the Lord or the deeds that He had wrought for Israel' (Judges 2:8-10). The people of Israel forgot God's wondrous acts; Israel turned to idolatry and, in so doing, summoned God's swift punishment: the deliverance of Israel to her enemies. But God is merciful and forgiving, and whenever Israel calls out to Him, He sends a judge to save them. The judges are inferior to the prophets who first led Israel. Indeed, despite the established and recurrent pattern in Judges of transgression, punishment, Israel's cry for help, and their subsequent deliverance, it is clear that God's patience wanes, and each new judge proves inferior to his predecessor.

The first judge about whom we receive a true story is Ehud son of Gera (chapter 3$)^{2}$ who carries out his work with complete faith. His successor, however, is Barak, ${ }^{3}$ in whose faith can be discerned a crack. When the prophetess Deborah summons Barak and commands him, in God's name, to set out and save the people, he balks: 'If you will go with me, I will go; if not, I will not go' (4:8). This slender fracture grows wider in the story of the judge Gideon who declares 
himself unwilling to take even one step without a sign from God (see $6: 17,31-40 ; 7: 9-16)$. Late in his life, just after his refusal to rule and establish his descendants as rulers over Israel (8:22-23), he ironically transforms Ophrah (his home town) into what appears to be a cultic center and ruling city. Gideon commits an unambiguous transgression when he erects there an ephod as his representation: 'There all Israel went astray after it, and it became a snare to Gideon and his household' $(8: 27)$. Gideon's punishment comes in the murder of seventy of his sons by their brother Abimelech, the son of Gideon's concubine, and Abimelech's rule in Shechem (chap. 9).

As the people of Israel continue to sin against God, so the quality of the judges sent to save them continues to decline: Jephthah, the son of a prostitute (11:1), rashly and needlessly makes a vow that ultimately leads to his daughter being offered as a burnt-offering (11:30-31;3440). If that were not enough, Jephthah's response to the Ephraimites' contentions is the massacre of forty-two thousand Ephraimites (12: 1-6), to be compared with Gideon who, when confronted with similar accusations by the Ephraimites, knew to resolve the tensions in such a way as to avoid unnecessary violence (8:1-3). Jephthah, hot-tempered and of rash judgement, chose the bloodbath.

Just as we think that no judge's behavior could worsen, we find the story of Samson: proof of the boundless depths of depravity. Samson proves himself the nadir of all the judges and after his death we hear loud voices calling for a king. Indeed, the stories that seal the book of Judges-stories that include explicit acts of anarchy and crime reaching even to civil war-are girdled by formulas that arouse our expectations for a king: 'In those days there was no king in Israel; every man did as he pleased' (17:6;21:25), while twice there appears an abbreviated formula $(11: 1 ; 19: 1)$. The monarchy will be established in the book of Samuel, and with it will grow the ever-increasing chasm in the relations between God and His people until, with no other choice, God expels them from Israel.

Even this brief overview of the history of Israel's leaders makes apparent how Israel's continued sins are punished with increasingly disappointing and incommensurate leadership. Samson occupies a distinct place as the last of the judges and the worst of all. After him will come the ultimate punishment: the establishment of the monarchy. 
The positioning of Samson's life story in biblical historiography and the fundamental significance of its placement does not necessarily attest to the original meaning of the story - the meaning it carried before it came to rest in the book of Judges. Before we look closely at the story, let's identify the distinctive characteristics of Samson that distinguish him from the other judges.

1. Samson's biography is significantly longer than that of any other judge. Four chapters long, his story occupies approximately twenty percent of the book of Judges.

2. Samson's physical dimensions are those of a giant, although this is indicated only by way of the description of his carrying the gates of Gaza (16:1-3). Only a giant would be capable of such a feat, grasping the two gateposts and the gate, as observed by the rabbis: 'R. Simeon the Pious said: Samson's shoulders measured sixty cubits, as it is said, »But Samson lay in bed only till midnight. At midnight he got up, grasped the doors of the town gate together with the two gateposts, and pulled them out along with the bar. He placed them on his shoulders»; and there is a tradition that the gates of Gaza are not less than sixty cubits [in width]' (BT Sotah 10a).

3. Samson does not act as the head of an army or tribe but confronts his enemies alone (at times even alienated from his countrymen who are willing to hand him over to the Philistines [15:9-13]).

4. Samson's battles are not those of his people or his tribe who are, in fact, in a state of peace with the enemy. Instead, Samson's battles are his own and revolve around romantic entanglements (see below).

5. Each of the other judges conducts only one war after which he presides over a peaceful era; Samson fights many battles.

6. Samson is the only of the judges whose entire life story-from birth until death-is recounted for the reader.

This singular figure invites our wonderment. How did these stories of sexual passions and scandals find their way into the history of God's redemption of Israel? What changes did the stories undergo before being allowed into the Holy Book? Indeed, the incorporation of the Samson stories into the chronicles of God's deliverance of Israel is perplexing, and not only because the hero seems so alien to the spirit of the Bible. Many of the details in the Samson stories are similar to those in mythological traditions, though the monotheistic worldview 
does not readily accommodate such mythologies. Accordingly, the stories underwent a process of de-mythologization before they could be included in the Holy Scriptures: stories were disentangled from their mythological origins and made to conform to a monotheistic belief system.

The rejection of the myth is accomplished surreptitiously, using what I call covert polemics: in the very telling of the tale, the storyteller rejects the story's mythological underpinnings, and transforms it in his new written version. We will examine and follow these covert polemics as they function in the story of Samson's birth. This is also the place to mention another relevant term: literary archaeology. This refers to the 'unearthing' of traditions which, having been deemed inadmissible by the Bible's writers, nonetheless continued their lives in the world of oral literature until, in the post-biblical period when the ideas and beliefs they conveyed were no longer viewed as threatening, they were written down. As opposed to the classic archaeologist who digs deeper and deeper in order to reveal more ancient strata, the literary archaeologist may in fact find more archaic layers of a story in later texts, from the Second Temple period (apocryphal books, Jewish Hellenistic texts), rabbinic literature, and so on. ${ }^{4}$

And now we turn to Samson's birth story (chapter 13). At first it appears that this account conforms to the accepted pattern of birth stories in the Bible, stories where a barren woman gives birth to a son (see the stories of the barren-women-turned-mothers such as Sarah, Rebecca, Rachel, Hanna, and the Shunamite woman). Even among these seemingly similar companions, however, the story of Samson's birth distinguishes itself. As we'll see below, it is particularly interesting to compare our story with those about the birth of Jesus in the New Testament.

A very different birth story-and one that remained closest to its mythological roots—can be found in Genesis 6:1-4. There we find the story of the Divine Beings ('sons of God') who came to earth and had relations with the 'daughters of man' which resulted in the birth of a race of giants, the 'heroes of old'. In this diluted mythological remnant, the offspring of the union are not, themselves, divine (as they would have been in the myth), nor do they ascend to heaven. Rather, 
they remain flesh and blood, mortal in every way-only their dimensions are larger than the normal human and they are heroes.

This story, as U. Cassuto rightly observed, ${ }^{5}$ does not come to tell something new, but rather to polemicize against a tradition that told about the relations between divine beings and mortal women, relations that had produced divine offspring. Such was an Ugaritic tradition according to which the god, $E l$, had relations with mortal woman and so were born to them Shachar and Shalem, who themselves became gods. ${ }^{6}$

Likewise, in the Greek mythological tradition we find a relevant story in the birth of Heracles, son of Zeus, father of the gods. Zeus arrived to Thebes when Heracles's mother, Alcmene, was alone (her husband, Amphytrion, was away on a military expedition), and, disguising himself as Amphytrion, entered her bed, had relations with her, and departed. A short while later the victorious Amphytrion returns and to his great consternation realizes that Alcmene believes she has been with him already the previous night. $\mathrm{He}$, too, has relations with his wife. From these two sexual encounters Alcmene gives birth to twins-twins who are very different from one another: the larger one, Heracles, resembles his father, the god Zeus, while the other, the son of Amphytrion, is but a human. (A particularly good version of the birth story of Heracles is found in Hesiod's 'The Shield of Heracles' lines 27-56. ) In contrast to this mythical story-in which Heracles becomes himself a god having been born from the sexual relations between a mortal woman and God-Samson's mother is barren, as are the other mothers in biblical stories that we listed above. In the biblical stories, then, there is a need for divine intervention-a miracle - not present in the myth, where the god's involvement stems from his own, sexual desire.

The wife of Manoah meets an angel of the Lord, and not God Himself, since it is not God's habit to walk among mortals. The one who appears to the woman as 'a man of God [who] looked like an angel of God, very frightening' (v. 6), proves his authority_-signals that his promise will in fact be fulfilled-with his unexplainable knowledge: 'You are barren and have borne no children' (v. 2). He then informs her of the birth of Samson, the son of a mortal mother. And still, we find in this story mythological remnants—or, more precisely, signs of 
the battle against the myth. The wife of Manoah stands in the center of the story-not Manoah, her husband, but her. The angel appears to the woman when she is alone, without her husband (similar to the experience of Alcmene, above), and when she reports the meeting to Manoah she says, 'A man of God came to me' (v. 6), using an ambiguous term that is often used with sexual connotations. After Manoah pleads with God to send the angel again, the angel does indeed return, again to Manoah's wife when she is 'sitting in the field and her husband Manoah was not with her' (v. 9). The 'field', of course, provides the perfect location for crimes, especially sexual crimes (see Deut 22: 25-26). Had the storyteller wanted the angel to appear to the woman again simply in order that she identify him, the angel could well have come to her when she was safe in the company of her husband! But of course this author sought to excise the fundamental mythological motif-according to which Samson's mother was impregnated by a god, resulting in the birth of a giant, a hero of tremendous strength-from this story.

The mythical tradition is denied here by way of partial admission, a method used often in the Bible: yes, the woman told her husband that the angel came to her (v. 6), but we ourselves know that he only appeared to her, and even her husband is certain of this, as he expresses when he asks God, 'let the man of God that You sent come to us again' (v. 8), and again when he reminds the angel that the angel 'spoke' with his wife (v. 11) - spoke and that's all! The angel of God comes to the woman a second time, again in order to show us that his 'coming' implies only his appearing to the woman, and this time she waits not a moment before she runs to call her husband (v. 9). In this we are reassured that despite their meeting in a field, without her husband being present (v. 9), there is no reason to suspect that any impure act occurred between the messenger and Manoah's wife.

The desire to blur the formerly mythical lines of the tradition is recognizable also in the absence of any etymology of Samson's name. The silence on this reflects the attempt to avoid any connection between Samson, Shimshon (iuana), and 'sun', shemesh (ana)—more exactly, the Sun God. The primary connection between Samson's name and the word for 'sun' was felt by the rabbis, who sought to evade the difficulty by offering their own etymology: 
R. Johanan also said: Samson was called by the name of the Holy One, blessed be He; as it is said, 'For the Lord God is a sun and a shield' (BT Sotah 10a). ${ }^{8}$

The potent relevance of the mythical story to the birth story was felt be Josephus Flavius, who lived in the world of Hellenistic beliefs and opinions. He also felt a need to address the troubling questions concerning the angel's meeting with Manoah's wife.

[Manoch] was moreover madly enamoured of his wife and hence inordinately jealous. Now once when his wife was alone, a specter appeared to her from God, in the likeness of a comely and tall youth, bringing her the good news of the approaching birth of a son through God's good providence-a son goodly and illustrious for strength, by whom, on his reaching man's estate, the Philistines would be afflicted. . . And having thus spoken the visitor departed, having come but to execute God's will. The woman, when her husband arrived, reported what she had heard from the angel, extolling the young man's comeliness and stature in such wise that he in his jealousy was driven by these praises to distraction and to conceive the suspicions that such passion arouses. But she, wishing to allay her husband's unreasonable distress, entreated God to send the angel again that her husband also might see him. And again by the grace of God the angel came, while they were in the suburb, and appeared to the woman when parted from her husband. She besought him to stay until she could fetch her husband and, obtaining his assent, went in pursuit of Manoch. But the husband, on beholding the angel, even then did not desist from his suspicion, and he requested him to repeat to him too all that he had revealed to his wife. The angel having declared that it would suffice that it should be made known to her alone, Manoch bade him say who he was, in order that on the birth of the child they might tender him their thanks and make him a present. He replied that he had need of naught, for it was not from want that he had announced this good news of the birth of a child; and though Manoch invited him to stay and partake of hospitality, he consented not. (Ant. V. 277-282). ${ }^{9}$

The other stories in the Bible about barren women who then give birth are much further from the mythic pattern, according to which the god has sexual relations with a woman. Even so, one particular expression in the story of Rachel's motherhood invites our notice: 'Now God remembered Rachel; God heeded her and opened her womb' (Gen 30: 22). We find here an expression that perhaps represents a vestige from 
when it was meant literally, and the god 'opened the womb' of the woman when he came to her, i.e. had relations with her. The mythical pattern was rejected by the Hebrew Bible but returns in the New Testament, though in a tempered form. In the Gospel of Matthew, Jesus' mother, Mary (who was not barren), becomes pregnant before she had been with her husband, just as with the mother of Heracles: 'When his mother Mary had been betrothed to Joseph, before they came together she was found to be with child of the Holy Spirit' (Matt 1:18). ${ }^{10}$ In his reputable telling of the story, the writer avoided giving a plastic description of God's impregnating Mary. Even more: Mary's remaining a virgin teaches us that no actual physical contact occurred. ${ }^{11}$

The obscuring of the tradition of Samson's birth, along with the elimination of any overt allusions to his size, is related also to the way in which Samson achieves his victories. It is not his strength that makes Samson triumphant, but the will of God and God's spirit that rests on him. Thus, for example, Samson stands before a huge crowd of Philistines in Lehi: 'When he reached Lehi, the Philistines came shouting to meet him. Thereupon the spirit of the Lord gripped him, and the ropes on his arms became like flax that catches fire; the bonds melted off his hands. He came upon a fresh jawbone of an ass and he picked it up; and with it he killed a thousand men' (15:14-15). Samson is proud indeed of his victory, giving no credit to God when he sings out his childishly jubilant song: 'With the jaw of an ass, Mass upon mass! With the jaw of an ass I have slain a thousand men' (v. 16). Immediately following this self-satisfied boasting, Samson becomes dramatically aware of the severe limitations of his power when he thirsts for water and cannot even help himself. He is forced to turn in prayer to God, and in his prayer he looks back and views his victory over the Philistines in the correct light: 'You Yourself have granted this great victory through Your servant ...' (v. 18).

The importance of the lesson that Samson (along with the readers of the story) learns - that the victory belongs to God and not to Samson- is described by Josephus Flavius:

Yet Samson, unduly proud of this feat, did not say that it was God's assistance that had brought it to pass, but ascribed the issue to his own valor, boasting of having with a jawbone prostrated some of his enemies and put the rest to rout through the terror 
that he inspired. But, being seized with a mighty thirst and recognizing that human valor is a thing of naught, he acknowledged that all was attributable to God and implored him not, in anger at any words of his, to deliver him into his enemies' hands, but to lend him aid in his dire need and to rescue him from his distress. And God, moved by his supplications, caused a spring of water to well out of a rock, sweet and abundant ... (Ant. V. 301-303). ${ }^{12}$

The writers of the midrash also understood Samson's predicament at Ein HaKoreh as representing a lesson for him. For them, Samson's thirst was not the result of his battles with his enemies, but of his prideful words: '»And he was very thirsty», One who talks a lot becomes thirsty' (Genesis Rabbah 98:13). The name of the spring that God splits open for Samson, 'Enhakkore (lit.: 'the spring of the one who cries out') of Lehi', perpetuates the memory of Samson's weakness - that he needed God's help and that he called to Him at his time of need.

It is not coincidental that this story seals the events that follow Samson's marriage to the woman from Timnah (chapters 14-15). From this place, the story's influence is heightened since the reader's final impressions are shaped by it. Here, suddenly, Samson is portrayed as an entirely passive figure who is completely dependent on God and who receives God's deliverance after his submissive prayer. ${ }^{13}$ In the same way, the stories of Samson's relations with Delilah (beginning in 16:4) — along with the entire Samson cycle — will close with God's answering Samson's desperate prayer, once again teaching the reader that only through God's power does Samson find the strength to overcome his enemies. Having been fetched from the prison to dance for the Philistines in their temple, Samson can only turn to God since, in the cutting of his hair, he had failed to uphold the requirements of his Nazirite status and so his strength had left him: 'Then Samson called to the Lord, „O Lord God! Please remember me, and give me strength just this once, O God, to take revenge of the Philistines, I only for one of my two eyes»' (16: 28). Though, once again, Samson cries out only on his own behalf, in order to take revenge against the Philistines for himself and not for the sake of Israel, still God will answer him and the temple of Dagon will collapse onto the Philistines and kill them. And note: the victory is not that of Samson but that of the God of Israel over the god of the Philistines in the latter's temple. The lords of the 
Philistines had credited their gods with the capture of Samson, 'Our god has delivered into our hands our enemy Samson' (16:23), and the song of the people echoed that claim, 'Our god has delivered into our hands the enemy who devastated our land, and who slew so many of us' (v. 24). However it was not the powers of Dagon that felled Samson but Samson's own weaknesses that caused him to break his Nazirite vows and be abandoned by his God. Samson's prayer to God and the destruction of Dagon in his temple reiterates the lesson that neither Samson nor the gods of the Philistines possessed any true power: that is the sole possession of the God of Israel.

I have already mentioned how all the wars of Samson revolve around the Philistine women on which he cast his eyes. The story about his marriage to the woman from Timnah pulls after it a chain of battles (chapters 14-15) that culminate in Samson's victory at Lehi. Afterwards there appears a short story, a sort of comic relief, that tells of Samson's going to a prostitute in Gaza and his successful escape (despite the ambush that the Philistines set up there) with the gates of Gaza on his shoulders (16:1-3). Since the story involved Samson's going only to a prostitute, and not his falling in love, it does not invite further, unwanted complications. ${ }^{14}$

Immediately after this, however, Samson falls in love again with a Philistine woman, this time with Delilah, the woman who will bring his end (16:4-31). The many similarities between these two love stories - the story of the woman from Timnah and that of Delilahare worth noting: in both stories the Philistines use Samson's beloved to tempt him to reveal his secrets. In the first, they persuade the woman of Timnah to reveal the answer to his riddle (14:15), while from Delilah they expect the secret of his strength and life (16:5). In both the woman succeeds in her mission after her repeated petitioning wears down Samson's defenses (14:16-17; 16:6-18). In both stories Samson's revelations cause him great harm, though simultaneously wreaking great devastation on the Philistines. In both cases, Samson causes the death of many Philistines precisely when he is their prisoner (15:14-17; 16:25-30). Both stories end, again, with God's coming to the aide of Samson after he calls out to Him in prayer (15:18-19;16:28). Alongside this similarity in the plots of both stories, we can also point to a marked similarity in language: 
1. The words of the Philistines to the woman: 'Coax your husband' (14:15); 'Coax him' (16:5).

2. The words of the women to Samson as each tries to persuade him to reveal his secret: 'You really hate me, you don't love me' (14:16); 'How can you say you love me' (16:15).

3. The particular manner of the women's persuasion: 'she nagged him so' (14:17); 'after she had nagged him' (16:16).

4. At Lehi, the Philistines bound Samson with 'two new ropes' (15: 13); Delilah ties Samson up with 'new ropes' (16:11-12).

5. At Lehi, the ropes loosened 'like flax that catches fire' (15:14); with Delilah, 'as a strand of tow comes apart at the touch of fire' (16:9).

At first, one might imagine that the story of Samson's death-the story of Samson and Deliliah - represents in fact a second, double rendering of the story of Samson's marriage (chapters 14-15). We must reject this possibility, I think, first of all because of the striking linguistic similarities. These similarities indicate a single writer behind both stories in chapters $14-15$ and $16 .{ }^{15}$ But the striking similarity between these narratives shouldn't distract us: the two episodes and their meanings should be understood in the context of Samson's biography, where particular significance must be granted to differences, to the growing severity of Samson's acts. Samson fails repeatedly to learn from his mistakes. Again and again he strays after a Philistine woman who betrays him to his enemies. Not only does Samson fail to learn from his experiences but he commits precisely the same mistakes, and his fate is sealed accordingly. The first time his heart is misled by a Philistine woman his disclosure is insignificant—-the answer to his riddle—and he pays greatly for it, with the loss of his wife and the setting in motion events that lead to his revenge on the Philistines. When he reveals his secret to Deliliah it is of a much more serious nature, involving the secret of his strength and life, and his misjudgment brings his death. Samson is a tragic hero, a hero whose character and unrestrained attraction to foreign women determines his bitter fate and pulls him to his inescapable end.

Though the stories from Samson's life revolve around women, they do not depict his physical pleasure (except for the story of his sleeping with the whore [16:1]). The biblical writer tends to curtail references to the sexual act as long as the story does not require it. Placing the 
stories into their present location-the Holy Scriptures-required leaving only the barest of hints and echoes of the erotic tradition that forms the foundation of this narrative. ${ }^{16}$ Evidence of the propensity of the biblical writer to diminish a story's sexual content as much as possible arises from a comparison of the story of Samson and Delilah (16:4-22) with its parallels.

1. Jael, wife of Heber the Kenite, kills Sisera both in the narrative version of the story (Judges 4:17-21) and in the poetic version (Judges 5:24-27).

2. Queen Esther forces the hand of Haman, the Jew's adversary, exposing him to the king during the wine feast (see especially Esther $7: 8)$.

3. Judith kills Holofernes the Assyrian general while naked, at the moment that Holofernes is certain of her willingness to lay with him (Judith 10-13).

4. The descriptions of the seductive, foreign woman in Prov 7:6-27 reveal strong similarities to our story: a foreigner entices the young man to come with her to her home to enjoy the pleasures of love, pleasures that will ultimately lead to his death at her hands.

In contrast to the stories about Jael and Sisera, Esther and Haman, and Judith and Holofernes-in which the reader's sympathies are aligned with the woman who saves her people from the foreign threat - in the story of Samson and Delilah we stand on the side of the Hebrew hero who betrays himself to the temptations of the seducing woman. This suggests the possibility that in fact the story originates in a Philistine tradition, where the tale was told from the perspective of Delilah, and where the fall of the 'foreign' hero, Samson, was cheered. ${ }^{17}$

The transformation of the Philistine tradition into a Hebrew one brought with it a number of changes: the woman no longer acts from patriotic impulse but for monetary reward (16:5), and the defeat of the hero is no longer permanent and final. Instead, he is given a chance to take revenge on his enemy and to deliver the final and devastating blow, of course with the help of the God of Israel.

We also see the jettisoning of erotic elements from the story. With Jael and Sisera we possess two stages in the Bible's taming of eroticism: in the poetic rendition we find the earlier version, while in 
the narrative, the later. ${ }^{18}$ Evidence of this process of tempering is found also in the other narrative traditions, including our own. Pointing out the common elements between these different traditions, either shared by all or some, will enable us to discern the modification of the original motif, as reflected in the story of Samson and Delilah.

In Antiquities of the Jews, Josephus Flavius writes that Delilah gave wine to Samson in order to then bind him: 'and while Samson was drunken [she] bound him with the shoots as firmly as possible' (Ant. V. 310). This detail is missing from the account in Judges 16, since Samson was a Nazirite and, we are told, concerning his Nazirite vows he broke only that concerning the cutting of his hair, for which he then lost his strength. But the drinking of wine appears in the other traditions: in both narrative and poem, the parched Sisera asks the woman for water (compare Gen 24:43), and she gives him milk in order to insure him of her sincerity and to invite his confidence in her. The rabbis looked for erotic elements in the story of Jael and Sisera and found it in Jael's milk, which they read as breast-milk (BT Nida 55b), but in another place they sensed that the drink was offered to intoxicate: '»She opened a skin of milk and gave him some to drink»... He drank, got drunk, and demanded to have intercourse with her' (Midrash HaGadol Genesis 23:1). Pseudo-Philo 31:6 states explicitly: 'And Jael took wine and mixed it with milk'. About Holofernes it is distinctly written that he was given wine on the last night: ' . . . he drank a great deal of wine, much more than he had ever drunk on a single day since he was born ... So Judith was left alone in the tent with Holofernes sprawled on his bed, dead drunk' (Judith 12:20-13:2), his murder made possible by the deep, drunken sleep into which he fell. Also in Esther we find that the king's anger against Haman was aroused at the wine feast that the queen prepared for him and Haman (Esth 7:1ff.).

The story of Samson and Delilah does not explicitly mention that sexual intercourse took place between the two. Instead we are told only that Delilah 'lulled him to sleep on her knees' (16:19). The rabbis, however, exposed the eroticism behind the verse in their midrash onthehapaxlegomenon, ËV2m) $\mathrm{K}^{*} \mathrm{t}$ ) $\leq \cdot \mathrm{U}$ ('andshepressedhim'; $\mathrm{v} .16$ ): 'What does »and she pressed him» mean? R. Isaac of the school of R. Ammi said: At the time of consummation, she detached herself from him' (BT Sotah 9b). 
Allusions to sexual relations are more obvious in the story of Jael and Sisera, especially in the poetic rendition: 'Between her legs he sank (kara), lay (nafal) outstretched (shakav), between her legs he sank (kara), lay (nafal) still; Where he sank (kara), there he lay (nafal) — destroyed' (Judg 5:27). The expression 'between her legs' appears in the Bible only in this verse and Deut 28:57, where the original implication is clear: 'the afterbirth that issues from between her legs'. Also the rabbis found this meaning in the poetic verses:

'Between her legs': This is a euphemistic expression. R. Johanan said: That profligate had seven sexual connections on that day, for it is said, 'Between her legs he sunk, he fell, he lay; at her feet he sunk, he fell, where he sunk, there he fell down dead.' (BT Yebamot 103a; see BT Horayot 1ob; BT Nazir 23a).

In this interpretation, Rabbi Johanan assigns an erotic meaning to each of the verbs: the seven acts of intercourse he refers to correspond to the seven verbs in the biblical verse. Indeed, while the verbs all describe the collapse and death of Sisera, they also attest to the erotic nature of the tradition: we hardly need to bring examples of the possible sexual connotations of the root shakav (cfa: lie down, sleep with); kara (grf: bow down, sink) carries this same meaning in Job 31: 10; while nafal (kpb: fall, prostrate), which is used to depict the death of Sisera both in the poetic and the narrative versions (4:22), appears in an erotic context in the parallel tradition in Esther: 'Haman was lying prostrate on the bed on which Esther reclined' ( $7: 8)$, and awakens the anger of the king who suspects Haman of trying to seduce the queen.

It is clear that Judges 5:27 alludes to a tradition in which Sisera dies while in Jael's bed with her. It uses the erotic terminology from the well-known tradition precisely in order to infuse those terms with new, non-erotic meaning, so that any suspicion that there took place any sexual act will be invalidated. In Judges 4 any hint that sexual intercourse took place is eliminated both by the use of the blanket for covering Sisera (v. 18) and also by keeping Jael away from the bed until after Sisera falls asleep. Sisera requests that Jael stand at the entrance of the tent in order to fend off any of his enemies. In Esther, as we saw, the motif is present but in an altered version: 'Haman was lying prostrate on the couch on which Esther reclined' (7:8). The sexual element is even more prominent in the book of Judith, especially when we 
read the words of Holofernes: 'For we will be disgraced if we let such a woman go without having her . . ' (12:12). When Judith comes to Holofernes's tent it is said: 'Holofernes was beside himself with desire, and his brain was reeling; and he was very eager to have relations with her. (From the day he had first seen her he had been watching for an opportunity to seduce her)' (12:16). Judith dresses herself in her finest clothes and jewelry in order to convey the impression that she intends to acquiesce to the general's advances. Sexual temptation appears clearly in the seductress's song in Proverbs, and especially in 7:18: 'Let us drink our fill of love till morning; Let us delight in amorous embrace'.

In Delilah's final attempt to uncover Samson's secret it is plainly stated that she lulls him to sleep (v. 19). Sleep enables Deliliah to overcome Samson and strip him of his strength. The fact that she lulls him to sleep 'on her knees' (Septuagint: 'between her knees') reminds us of the words 'between her legs' in Judg 5:27. Even so, our mild story refrains from implying that the sleep came after drink and sexual activity.

In the story of Jael and Sisera, Sisera's sleep comes after his exhausting escape on foot (4:15). Only in Judith does the author combine the element of sleep with drink (13:2ff.), where Holofernes's deep sleep makes it possible for Judith to behead him, exactly as in the story of Jael and Sisera. ${ }^{19}$

We have seen how the story of the life of Samson hides much from the reader, and how the Book of Judges has deleted from the story elements that were deemed improper for the book's placement among the Holy Scriptures. Erotic elements were torn from the story while Samson was transformed from a mythological hero, the son of a god, to a mere mortal whose extraordinary strength came through the spirit of God that rested with him so long as he kept his Nazirite vows. The biblical storyteller could not prevent the story of Samson from entering into the biblical corpus since it was a tale of tremendous popularity. He thus told it in such a way as to bring it closer to his monotheistic beliefs and world-view. In its 'biblical' form the story does not bring honor to the figure of Samson, and so his placement as the last of the judges in the Book of Judges. Samson represents the worst of all the judges; in his 
wake even the institution of the monarchy appears a desirable solution to the problems of leadership.

\section{Notes}

1. Also the names of the books of the Former Prophets attest to the attention paid to the leadership: Joshua, Judges, Samuel, and Kings. In the Septuagint the books of Samuel and Kings become four parts of one book: 1-4 Kings $(\mathrm{B} \alpha \sigma \iota \lambda \varepsilon \imath \alpha \imath)$.

2. Othniel the Kenizzite, the first judge, is used in Judges to link chapter 1 (see v. 13) to the rest of the book. Othniel's placement as the first judge also supplies a judge - the one and only-from the tribe of Judah. What we have about Othniel (3:7-11) represents nothing but formulas and expressions typical of the Deuteronomistic editor of the book of Judges, and not a story about his war against Cushanrishathaim.

3. The single mention of Shamgar (in 3:31) breaks the continuity of the narrative between Ehud's life and the statement of his death (4:1). The mention of Shamgar is an interpretative gloss whose purpose was to identify the anonymous Shamgar son of Anath who is mentioned in the Song of Deborah: 'In the days of Shamgar son of Anath, in the days of Jael, caravans ceased, and wayfarers went by roundabout paths' (5:6). On a possible Hurrite identification of the Song's Shamgar, see Maisler, 1934.

4. Examples of covert polemics that are revealed by literary archaeology can be found in Zakovitch, 1997; and Zakovitch, 1999.

5. Cassuto, 1973.

6. Cassuto, 1973, 23.

7. For additional sources in classical literature on the birth of Heracles, see Graves, 1960, 87-8.

8. It is worthwhile also to note that Samson operated in the area of Beit Shemesh, a city whose name attests to the worship of the sun-god there. See: Moore, $1895,325$.

9. See: Thackery and Marcus, 1988, 125-7.

10. A strong resemblance to the birth story of Samson can be found in the account of the birth of Jesus in the Gospel of Luke (chapters 1-2).

11. For an analysis of the birth stories in the New Testament, see: Brown, 1979.

12. See: Thackery and Marcus, 1988, 137.

13. See: Crenshaw, 1978, 90.

14. The story of Samson and the prostitute bears a striking similarity to the story of the prostitute Rahab (Joshua 2), except that the latter is written from the point of view of the woman, who exposes the incompetence of Joshua's spies as she manipulates them with great success. Rahab, who acts decisively despite the passive and stumbling spies, manages to save her own life and those of her family. The story in Judges, on the other hand, is told from the male's point of view and concentrates exclusively on Samson's own heroism, while the woman functions only as a sexual object. See: Zakovitch, 1990.

15. The same conclusion is reached through computer-assisted linguistic analysis. See: Radday, 1977, 496-7.

16. The removal of sexual elements in order to conform to a specific social 


\section{From Bible to Midrash}

context, such as children, is a known phenomenon in the world of international folklore. The original versions of Sleeping Beauty, Snow White, Rapunzel, and Cinderella, are not so innocent as they are now familiar to us from collections of children's fairytales. See: Stone, 1978, 46-7.

17. See: Frazer, 1923, 282.

18. See Zakovitch, 1981.

19. Further evidence of the originally erotic nature of Samson's life story is found in the unambiguous connections between it and Song of Songs, the collection of erotic poems in the Bible; compare Judg 14:5-9 and Song 5:1; Judg 15:5-6 and Song 2:15; Judg 16:13-14 and Song 7:6.

\section{Works Cited}

Brown, R. E. 1979. The Birth of the Messiah-A Commentary on the Infancy Narratives in Matthew and Luke. New York.

Cassuto, U. 1973. 'The Episode of the Sons of God and the Daughters of Man (Genesis 6:1-3)'. In Biblical and Oriental Studies. Vol. 1: Bible: 17-28. Jerusalem: Magnes Press.

Crenshaw, J. L. 1978. Samson-A Secret Betrayed, a Vow Ignored. Atlanta.

Frazer, J. G. 1923. Folklore in the Old Testament, Studies in Comparative Religion Legend and Law (abridged edition). New York.

Graves, R. 1960. The Greek Myths. Vol. 2. Harmondsworth.

Maisler, E. 1934. 'Shamgar Ben Anat'. PEQ 66: 192-4.

Moore, G. F. 1895. Judges. International Critical Commentary. Edinburgh.

Radday, Y. T. 1977. 'The Book of Judges Examined by Statistical Linguistics'. Biblica 58: 469-99.

Stone, K. 1978. 'Things Walt Disney Never Told Us'. In C. R. Farrer (ed.), Women in Folklore. Austin: $42-50$.

Thackery, H. St. J. and R. Marcus. 1988. Josephus with an English Translation. Vol. 5. The Loeb Classical Library. London.

Zakovitch, Y. 1981. 'Siseras Tod'. ZAW 93: 364-73.

- 1990. 'Humor and Theology, or: The Successful Failure of Israelite IntelligenceA Literary Folkloric Approach to Joshua 2'. In Text and Tradition, edited by S. Niditch, 75-98. Atlanta.

-. 1997. 'For by His Hand the Sun Stood (Ben Sira 46:6) —A Chapter in Literary Archaeology'. In Tehillah Le'Moshe: Biblical and Judaic Studies in Honor of Moshe Greenberg: $107^{*}-14^{*}$ (Hebrew). Winona Lake: Eisenbrauns.

-. 1999. 'The Exodus from Ur of the Chaldeans-A Chapter in Literary Archaeology'. In Ki Baruch Hu-Ancient Near Eastern, Biblical and Judaic Studies in Honor of B.A. Levine: 429-39. Winona Lake: Eisenbrauns. 